\title{
NUMERICAL MODELLING APPLICATIONS ON FRACTURE PREDICTIONS: AN EXAMPLE FROM THE BLUE LIAS FORMATION IN KILVE, UK
}

\section{PENERAPAN PERMODELAN NUMERIK PADA PREDIKSI REKAHAN: SEBUAH CONTOH DARI FORMASI BLUE LIAS DI KILVE, UK}

\author{
Adi Patria ${ }^{1,2}$ \\ ${ }^{1}$ Royal Holloway, University of London \\ ${ }^{2}$ Research Center for Geotechnology, Indonesian Institute of Science (LIPI)
}

\begin{abstract}
Numerical modeling using Comsol Multiphysics, with Finite Element Method, has been carried out to study fracture initiation, linkage, and deflection of the Blue Lias Formation. Data were from outcrop observation where hydrofractures were well observed. Three models were set up to understand how fractures initiated, linked and arrested. The Young's modulus of shales (Esh) was set with the value of $1 \mathrm{GPa}, 5 \mathrm{GPa}$, and $10 \mathrm{GPa}$. The fluid excess pressure was applied with the value of $5 \mathrm{MPa}, 10$ $\mathrm{MPa}$, and $15 \mathrm{MPa}$. The Young's modulus of the limestone (Elst) was a constant at $10 \mathrm{GPa}$. The first model showed how the overburden induces fracture initiation. The results indicated that tensile stress concentrated only within limestone and favour to form fractures. The second model was about linking of fractures. The result explained that shear stress was dominantly concentrated in limestone layers. Previous hydrofractures possibly linked up forming shear fractures and en-echelon fractures. The third
\end{abstract}

Naskah masuk : 6 Maret 2018

Naskah direvisi : 12 Maret 2018

Naskah diterima : 16 Oktober 2018

Adi Patria

Pusat Penelitian Geoteknologi, LIPI

Jl. Sangkuriang Bandung 40135

Email : adi.patria@lipi.go.id model was run to understand fracture propagation and deflection. The result was that tensile stress concentrated at the hydrofracture tips close to the contacts between limestone and shale. Hydrofractures were deflected, and in some places, hydrofractures were likely started to propagate through shale.

Keywords: Fluid excess pressure, hydrofracture, numerical modelling, Young's modulus.

ABSTRAK Permodelan numerik dengan Comsol Multiphysics berdasarkan metode Elemen Terbatas dilakukan untuk mempelajari inisiasi, hubungan, dan defleksi rekahan Formasi Blue Lias. Data berasal dari observasi singkapan dimana hydrofracture teramati. Tiga model dibuat untuk memahami bagaimana rekahan terinisiasi, terhubung, terambatkan dan terhenti. Modulus Young's batulempung (Esh) diatur dengan nilai 1 $\mathrm{GPa}, 5 \mathrm{GPa}$, dan $10 \mathrm{GPa}$. Tekanan kelebihan cairan (fluid excess pressure) yang diterapkan sebesar $5 \mathrm{MPa}, 10 \mathrm{MPa}$, dan $15 \mathrm{MPa}$. Modulus Young's batugamping (Elst) konstan sebesar 10 $G P a$. Model pertama menunjukkan bagaimana pembebanan mempengaruhi inisiasi rekahan. Hasil perhitungan menunjukkan bahwa tekanan tarik terkonsentrasi hanya pada lapisan batugamping dan memungkinkan terbentuknya rekahan. Model kedua mengenai hubungan rekahan. Model menunjukkan bahwa tekanan geser terkonsentrasi pada lapisan batugamping secara dominan. Hydrofracture yang telah ada akan terhubung membentuk rekahan geser and rekahan en-echelon. Model ketiga dihitung untuk memahami perambatan dan defleksi rekahan. Hasilnya menunjukkan bahwa tekanan tarik terkonsentrasi pada ujung hydrofracture dekat 
kontak lapisan batugamping dan batulempung. Hydrofracture terdefleksi dan pada beberapa titik mulai merambat menembus batulempung.

Kata Kunci: Fluid excess pressure, rekahan hidro, permodelan numerik, Modulus Young.

\section{INTRODUCTION}

Fracture studies have been developed in the last decade. Recent studies have approached using the numerical modelling technique to understand the behaviour of fracture (Brenner and Gudmundsson, 2002; Philipp, Afșar and Gudmundsson, 2013; Khoei et al., 2015; Mohammadnejad and Andrade, 2016). In shale gas concept, fluid flow is controlled by fractured media in impermeable layer instead of porous media (Ahr, 2008; Larsen \& Gudmundsson, 2010; Gillespie et al., 2001). Gas is extracted from shale by fracturing rock body so that permeability increases and gas flow to the surface. It is important for the geologist to understand fracture behaviour including how fractures develop and arrest so that risk of fracturing can be minimized.

For this study, the term of hydrofracture is referring to fluid-driven rock fractures, including joints, mineral veins, and dykes (Gudmundsson,
2011; Bons et al., 2012). Hydrofractures act conduit for fluid transport, such as shale gas and fractured reservoir. The Blue Lias Formation in Kilve was chosen as an example. The Blue Lias Formation consists of interbedding of shales and limestones (Peacock, 2002; Glen et al., 2005). Shale is dark grey and incompetent with the thickness ranging $10 \mathrm{~cm}$ to $150 \mathrm{~cm}$. Limestone is generally light grey, fine-sand grained, competent with thickness $10 \mathrm{~cm}$ to $80 \mathrm{~cm}$. The Lias formation is deposited in the shallow marine environment at Jurassic and deposited during a phase of continued rifting of Bristol Channel Basin (Matte, 2001). The location of the study area is presented on Figure 1. The objective of this study is to conduct numerical modelling on fracture development in the Blue Lias Formation in Kilve and understand how fractures develop. The result of this study can be analogue of fracturing for reservoir.

\section{Concept Overview}

Modelling of stress, strain and displacement caused by applied loads on the body of rock can be done using numerical modelling technique (e.g. Brenner and Gudmundsson, 2002; Philipp, Afşar and Gudmundsson, 2013; Khoei et al., 2015; Mohammadnejad and Andrade, 2016). Models

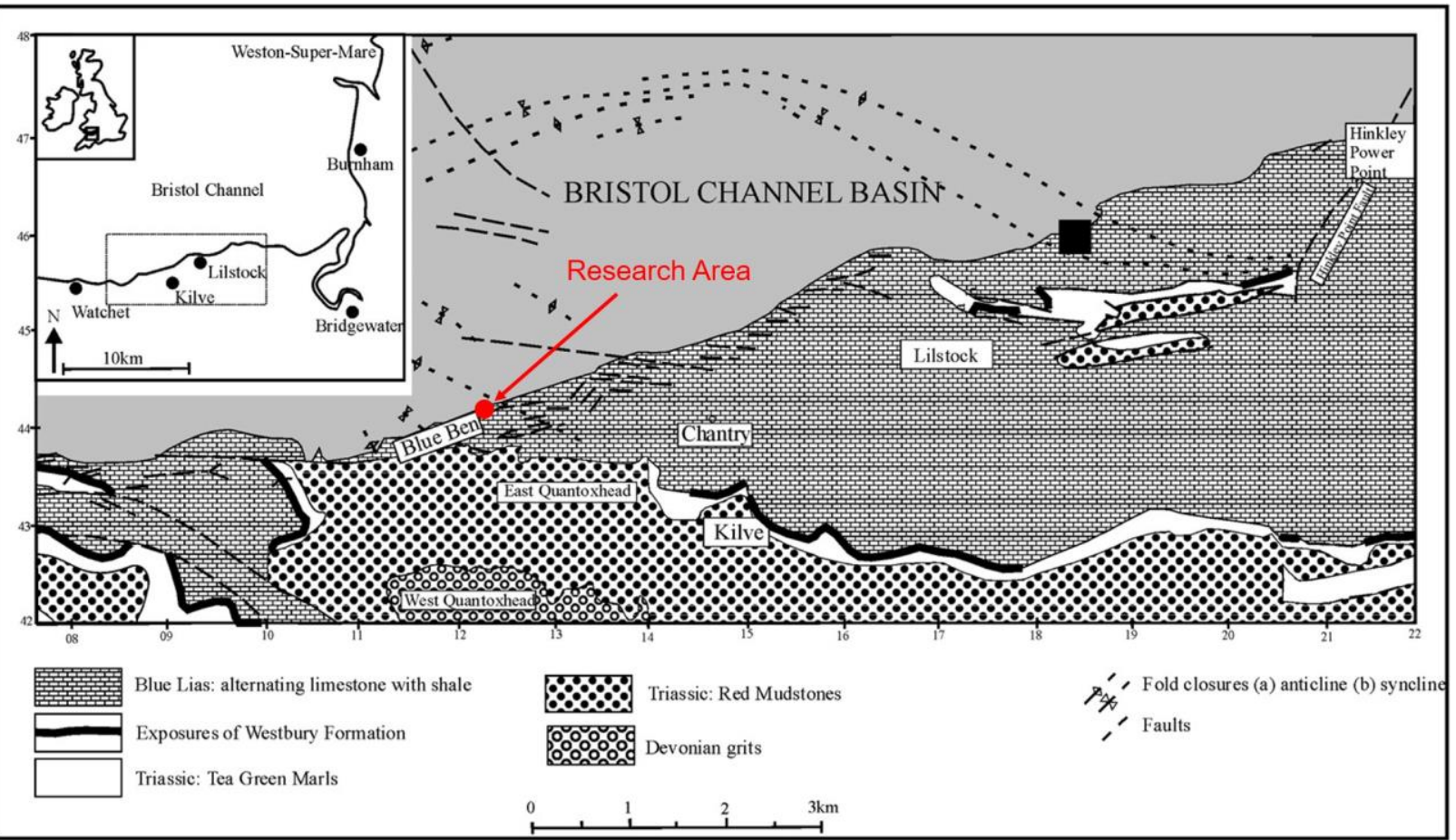

Figure 1. Location map of the study area (modified after Belayneh and Cosgrove, 2010). The inset map shows the location of the Bristol Channel Basin and the black rectangle shows the location of the study area. 
can be solved by using discrete elements. For each element, solution is the result of differential equation. This helps geologist to understand local stress fields, the direction of principal stress and fracture propagation in rock body.

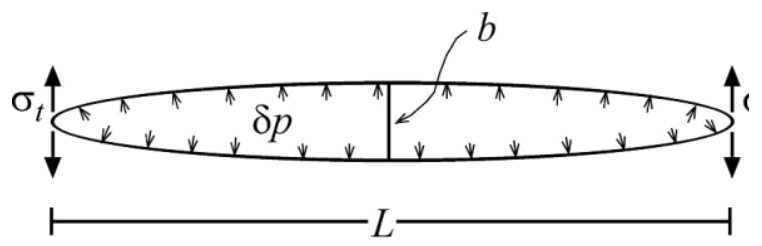

Figure 2. Elliptical fracture with fluid excess pressure causing tensile stress concentration at its tip.

Fracture initiation depends on the stress conditions at the source (Eq. 1), whereas fracture propagation depends on the stress conditions at the fracture tip (e.g. Valko and Economides, 1995). Hydrofractures generally start when sum of the lithostatic stress $\left(p_{l}\right)$ at a certain depth and the fluid excess pressure $\left(p_{e}\right)$ within rock become equal to the sum of the minimum principal compressive stress $\left(\sigma_{3}\right)$ in the roof of the source and in situ tensile strength $\left(T_{0}\right)$ of the rock in the roof so that the roof ruptures in extension (Gudmundsson et al., 2002).

$$
p_{l}+p_{e}=\sigma_{3}+T_{0}
$$

Fracture propagation depends on the induced tensile stress concentration at the tip of fracture (Figure 2.). This tensile strength is triggered by the excess fluid pressure in the fracture as well as its aperture and length (Pompe, 1971; Maugis, 2000). The solution of maximum tensile stress at fracture (Eq. 2) is given by (Peterson, 1955; Maugis, 2000).
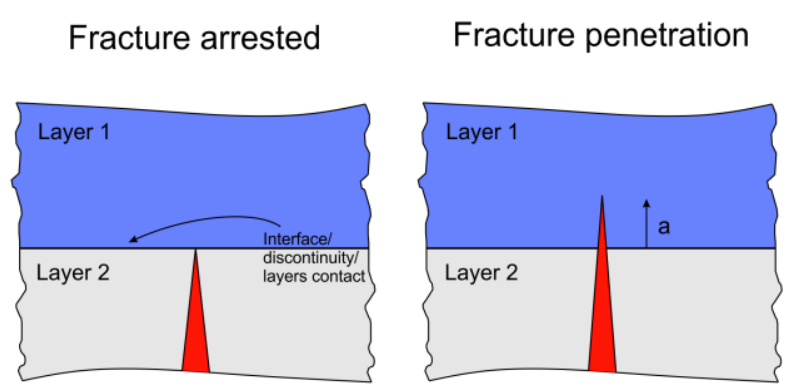
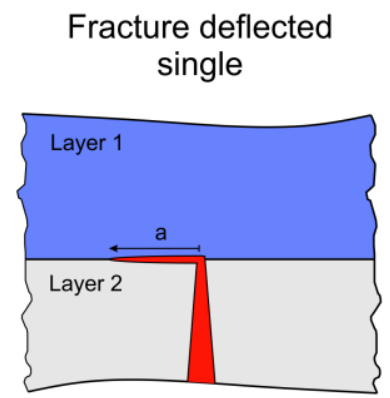

Where $P_{e}$ is the fluid excess pressure within the fracture. $L$ is a length of elliptical fracture and $b$ is maximum width of aperture of fracture if modelled as ellipses.

There are three mechanisms to explain fractures become arrested, deflected, and crack the contact of layers (Figure 3 ) described in previous authors (Zhang et al., 2007; Larsen et al., 2010; Gudmundsson, 2011). They are:

- Stress barrier; A propagating fracture in a strike dimension could arrest when it reaches a previous fracture. In the field, the result of this type of mechanism can be observed as an orthogonal joint system. It is assumed that when a new fracture propagates, the previous fracture is still filled by fluid, acting as a free surface which does not accommodate shear stress. The direction of maximum horizontal stress tends to be affected in direction of the old fractures.

- Cook Gordon delamination; An induced tensile stress ahead of the propagating hydrofracture, parallel to contact between layers.

- Elastic mismatch; Arrested fractures happen because of the difference of material toughness at the contact between layers where fractures propagate into and the elastic mismatch layers.

Figure 3. Fracture termination possibilities when a fracture reaches a mechanical boundary. a) fracture is arrested b) fracture penetration c) and d) fracture is deflected (after Falcão, 2013). 


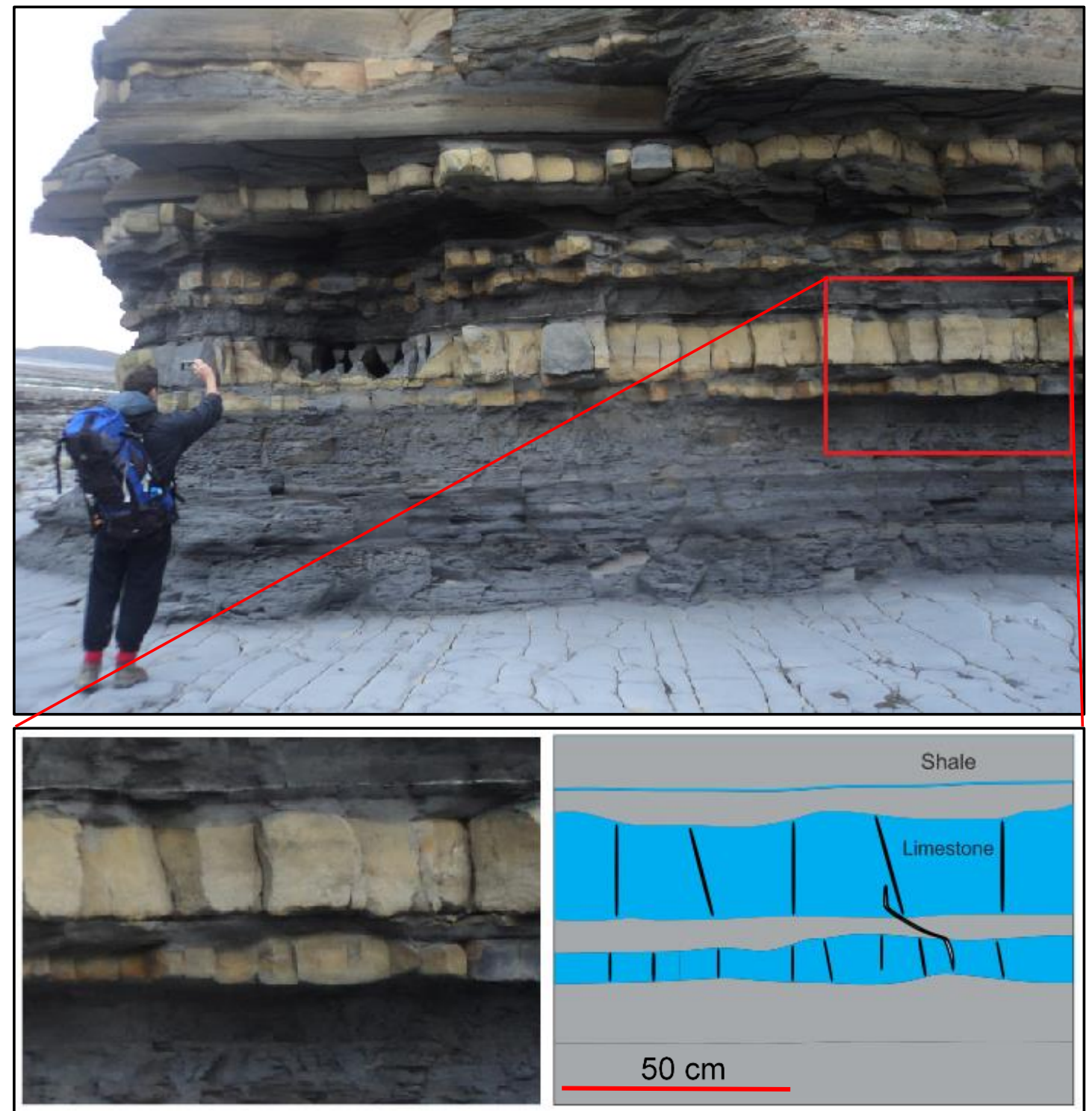

Figure 4. The outcrop that used for model. It consists of interbedding of shales and limestones. Red box indicates geometry for numerical modelling. Shale layers are grey and limestone layers are blue. Fractures are indicated by black.

\section{METHODS}

Outcrop observation on the Blue Lias Formation was carried out during a field trip in Kilve, UK. Data from the field was then digitized (Figure 4) so it can be used for numerical modelling using Comsol Multiphysics with Finite Element Method (FEM). The model setup can be seen in Figure 5. This method divides the model into series of small discrete called finite element. Models were fixed at the corner of rectangular to follow continuum mechanics theory.
The geometry of the model was only made in two dimensions. Models were focused on two conditions. The first was for predicting fracture development of rock under overburden condition. The second one was for simulating stress concentration and predicting fracture linkage, propagation, and deflection in the Blue Lias Formation if these fractured rocks are in the determined condition. For all model, it was assumed that the lithologies were solid media with no porosity so that the fluid excess pressure only works on hydrofractures, and the Poisson ration of shale and limestone was 0.25 . 


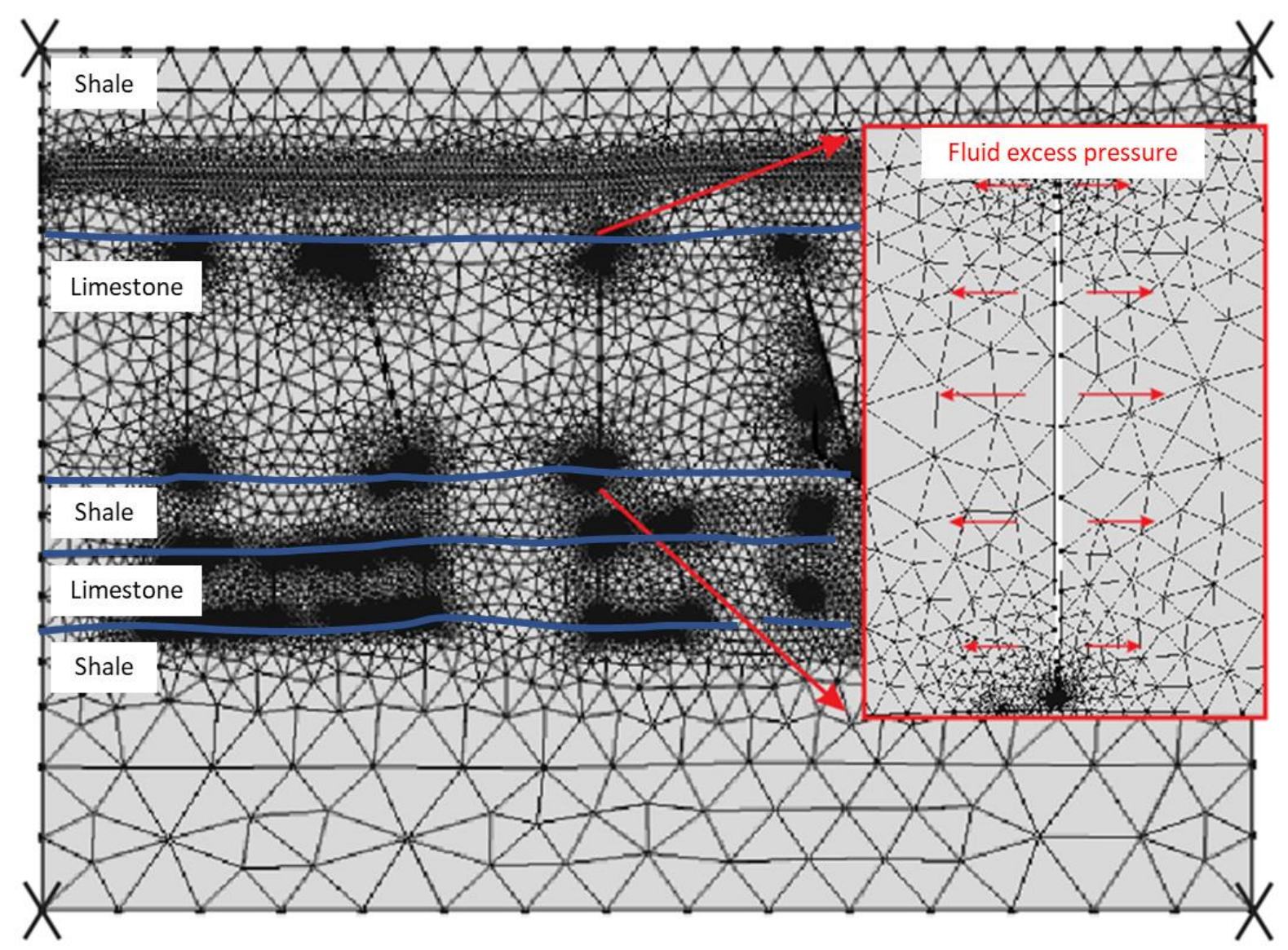

Figure 5. The boundary condition for model 2. Model is fixed at the corner.

\section{RESULTS AND DISCUSSION}

\section{Model 1 Fracture Initiation}

The model was created using following the boundary condition. It was assumed that there was no fracture when the overburden or vertical stress $\left(S_{v}\right)$ worked on the top and bottom of the boundary. If it was assumed that the formation was experienced $3000 \mathrm{~m}$ overburden (based on burial history suggested by Holford et al., 2005), then vertical stress can be determined using equation $S_{v}=\rho^{*} g * h$ (assuming $\rho=2500 \mathrm{~kg} / \mathrm{m}^{3}$ and $\mathrm{g}=9.8$ $\mathrm{m} / \mathrm{s}^{2}$ ). The vertical stress was $74 \mathrm{MPa}$. The Young's modulus of the limestone $\left(E_{l s t}\right)$ was constant at $10 \mathrm{GPa}$. On the other hand, Young's modulus of shale $\left(E_{s h}\right)$ is set vary $1 \mathrm{GPa}, 5 \mathrm{GPa}$ and $10 \mathrm{GPa}$.

The result shows that tensile stress $\left(\sigma_{3}\right)$ concentration covered only stiff layer (limestone) and is not concentrated in shale layers if there is a contrast in Young's modulus between limestone and shale (Figure 6). If tensile strength of limestone is $6 \mathrm{MPa}$ so that area of cyan to dark red colour is potentially fractured. If the there was no different in Young's modulus, tensile stress is concentrated in all layers. It is also observed that the contrast in Young's Modulus affects the stress concentration in limestone. Figure 6A shows that the tensile stress that concentrated in limestone is dominated by $20 \mathrm{MPa}$ while in Figure $6 \mathrm{~B}$ the maximum tensile stress in limestone is vary from $8 \mathrm{MPa}$ to $16 \mathrm{MPa}$.

Based on model 1, the limestone layers start being fractured within layers due to the overburden of $3000 \mathrm{~m}$ depth when Young's modulus of shale is $1 \mathrm{GPa}$. Tensile stress is concentrated only within limestone layers because limestone is stiffer than shale. Stress is concentrated in the whole body of rocks when there is no contrast in Young's modulus. It also can be inferred that present-day fractures in limestone layer were possibly formed at $3000 \mathrm{~m}$ depth and in the condition where Young's modulus of shale was less than or equal to $5 \mathrm{GPa}$. The tensile stress concentration is fairly distributed in shale and limestone layers if there is no difference in Young modulus of rock layer. 


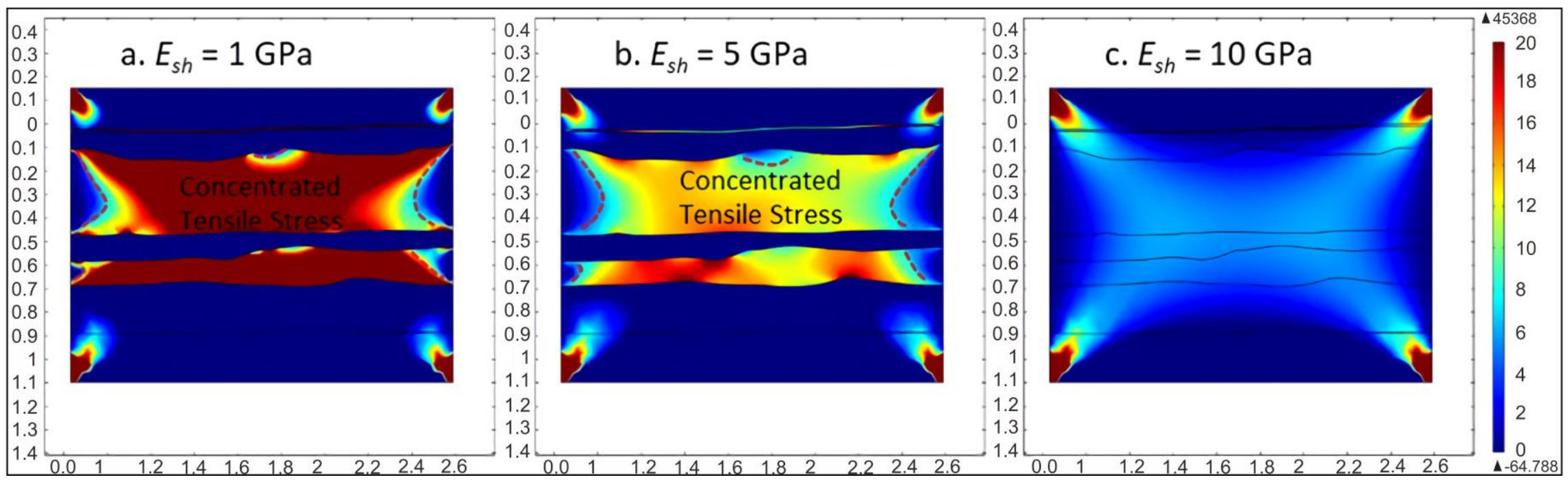

Figure 6. Tensile stress concentration as function of value of the Young's modulus of shale. $S v$ is according to overburden of $3000 \mathrm{~m}$ depth. Light blue shows the value of $6 \mathrm{MPa}$ and indicates where the stress is high enough to overcome tensile strength of rocks and so fractures is likely initiated. The colours scale indicates stresses ranging from 0 to $20 \mathrm{MPa}$. Please note that tensile stress concentration at the corner of model must be neglected. It is occurred due to fixed corner of model. 


\section{Model 2 Fracture Linkage}

This model was built to simulate fractures linkage between hydrofractures in limestone layers across shale layer and within limestone layers. Hydrofractures were already existed in limestone layers as seen present day. Fluid excess pressure worked on hydrofractures as minimum compressive stress $\left(\sigma_{3}\right)$. In this model, Young's modulus of shale $\left(E_{s h}\right)$ was set with value $1 \mathrm{GPa}$, $5 \mathrm{GPa}$ and $10 \mathrm{GPa}$. Fluid excess pressure was applied with value $5 \mathrm{MPa}, 10 \mathrm{MPa}$ and $15 \mathrm{MPa}$ representing. The Young's modulus of the limestone $\left(E_{l s t}\right)$ was constant at $10 \mathrm{GPa}$.
The result (Figure 7) shows that shear stress is concentrated in limestone layers. It indicates that the difference between $E_{l s t}$ and $E_{s h}$ influence shear stress concentration. It shows that If $E_{s h}$ is $1 \mathrm{GPa}$, shear stress concentration is in limestone layers while if the $E_{s h}=5 \mathrm{GPa}$ or $10 \mathrm{GPa}$ the shear stress is fairly distributed not only limestone but also in shale layers. Hydrofractures start to link up if the condition is favourable where shear stress overcome the shear strength of $6 \mathrm{MPa}$. Hydrofractures likely link up in the situation where $E_{s h}$ is $5 \mathrm{GPa}$ and fluid excess pressure is 10 $\mathrm{MPa}$. In shale, shear stress is concentrated close to

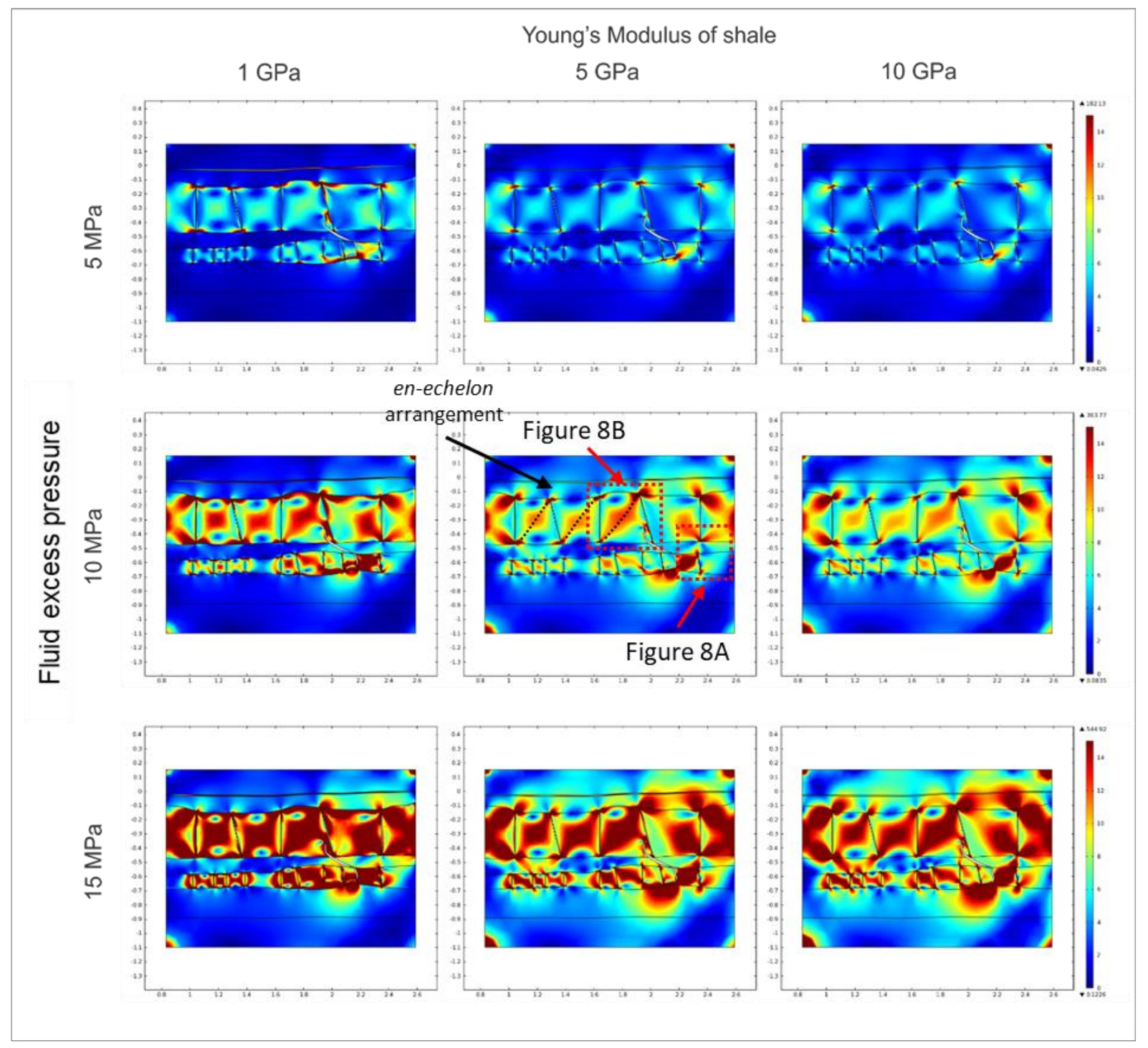

Figure 7. Shear stress concentration for model 2. Light blue shows the value of $6 \mathrm{MPa}$ and indicates where the stress is high enough to overcome the shear strength of the rock and so two previous fractures is likely to link. The colours bar ranges from 0 to $15 \mathrm{MPa}$. Probability of fracture linkage increases from left top corner to right bottom corner. 

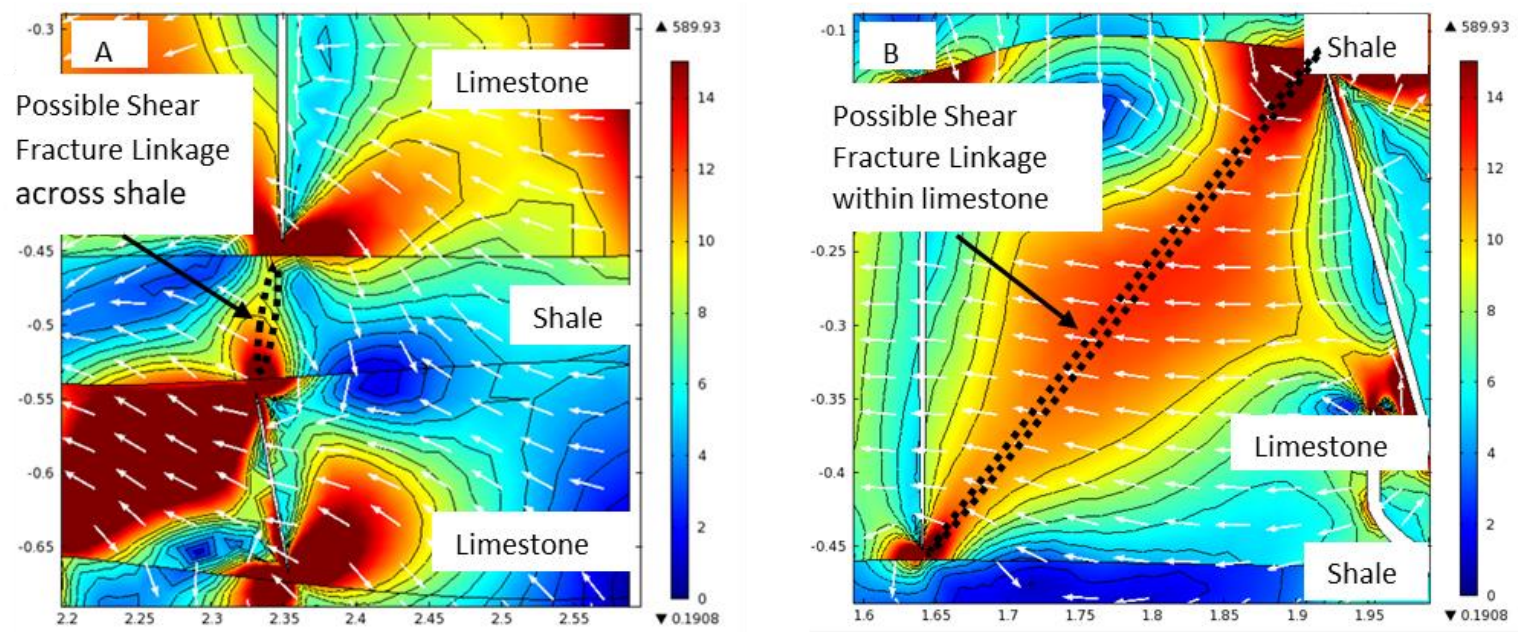

Figure 8. Detail of numerical modelling of model 2 under condition where Young's modulus of shale is 5 $\mathrm{GPa}$ and fluid excess pressure is $10 \mathrm{MPa}$ showing A). Possible fracture linkage through shale by shear fracture. B). Fractures linkage within limestone with en-echelon arrangement. Black dotted line is area where shear fracture possibly formed. White stick arrows represent direction of $\sigma_{l}$.

the tip of previous hydrofractures and shear stress ranges 8 - $14 \mathrm{MPa}$. Under these conditions, fracture is likely formed as it has overcome the shear strength, forming fracture linkage (Figure 8A). In same condition, shear stress is also concentrated within limestone. As seen in Figure $8 \mathrm{~B}$, the concentration is oriented oblique to the previous hydrofractures, from top tip of the rightside hydrofracture to the bottom tip of the left-side hydrofracture (Figure 8B). The fracture linkage connects the two hydrofractures with same orientation of the stress concentration and could form en-echelon arrangement of shear fractures (for example: see the orientation of the shear stress concentration at the situation where $E_{s h}$ is $5 \mathrm{GPa}$ and fluid excess pressure is $10 \mathrm{MPa}$ ).

In model 2, the decrease of contrast in Young's modulus and the increase of fluid excess pressure would increase the probability fracture linkage between previous hydrofractures. The fractures linkage can be formed in two types. The first is inter limestone layers through shale layer, forming a shear fracture. This type of linkage is expected to be formed when difference in stiffness of both layers is less than $5 \mathrm{GPa}$ and fluid excess pressure is greater than $10 \mathrm{MPa}$, so shear stress concentration increases in shale layers and shear fractures is possibly formed linking previous hydrofractures at above and below. The other type is the linkage between hydrofractures within limestone layers, connecting previous hydrofractures in oblique orientation and forming en-echelon arrangement. If there is a significant contrast in Young's modulus (greater than $5 \mathrm{GPa}$ ), shear stress is mostly concentrated in limestone so that shear fracture is only developed within limestone layers, connecting the upper part of one hydrofracture with the lower part of another hydrofracture.

\section{Model 3 Fracture Propagation and Deflection}

The model was built to show fracture propagation from limestone layers through shale layers if there is excess fluid pressure work on fracture, and fracture deflection within the limestone. The variation of Young's modulus of shale, Young's modulus of limestone and fluid excess pressure are set similar to model 2, fracture linkage. Tensile strength of rocks was $6 \mathrm{MPa}$. Previous hydrofractures could be arrested at the contact like in the field or deflected at the contact. Moreover, the hydrofractures would propagate through shale.

The result (Figure 9) show that tensile stress is concentrated at hydrofractures tips and mostly limited by contact between limestone and shale layers. It shows that the difference between $E_{l s t}$ and $E_{s h}$ influence tensile stress concentration. As Young's modulus of shale increases and the fluid excess pressure rise, the tensile stress concentration is also occurred in shale layers, indicating that hydrofracture likely propagates. Hydrofractures tend to be deflected if the tensile 


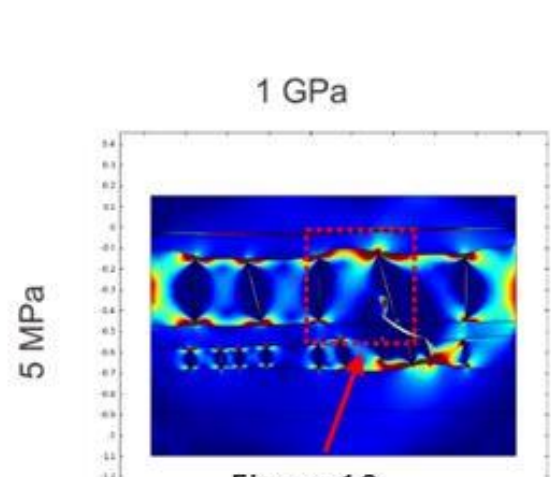

Figure 10
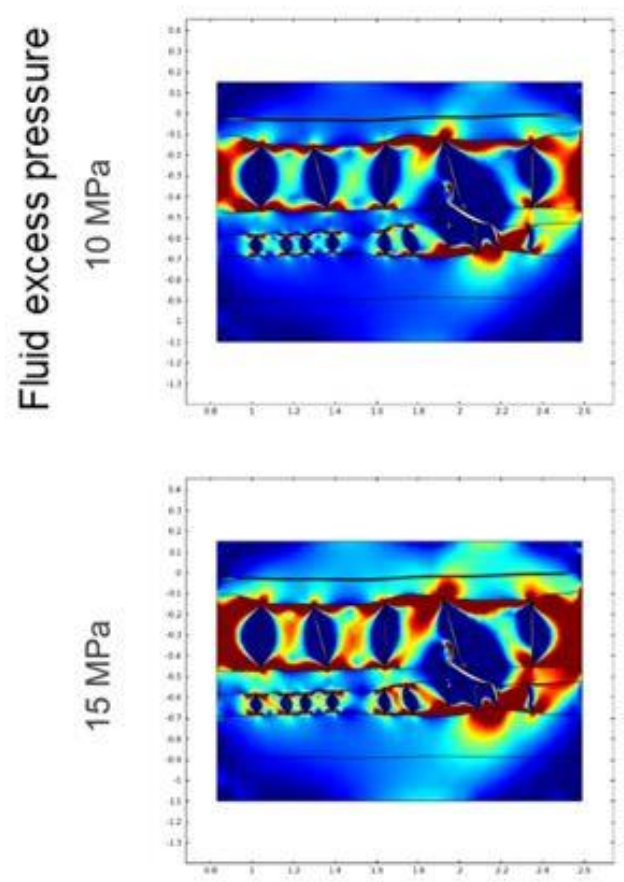

Young's Modulus of shale
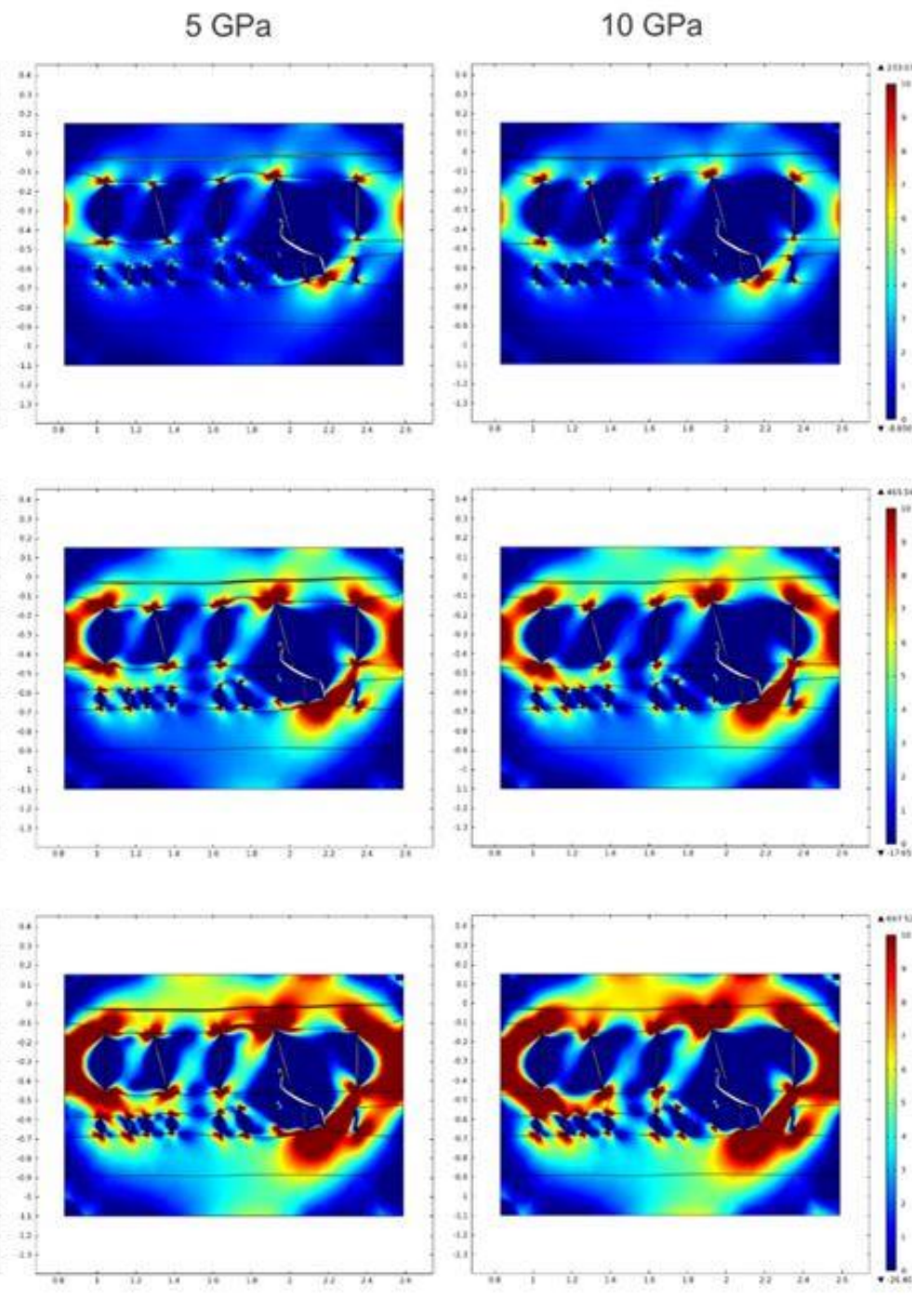

Figure 9. Induced tensile stress concentration for model 3. Yellow shows the value of $6 \mathrm{MPa}$ and indicates where the stress is high enough to overcome the tensile strength of the rock and new fractures is likely to propagate. The colours bar ranges from 0 to $10 \mathrm{MPa}$. Probability of fracture propagation increases from left top corner to right bottom corner.

stress concentration is only limited in limestone layer. The tensile stress concentration is limited in limestone layers if the contrast in Young modulus is significant. For example, see figure 10. The condition is where $E_{s h}$ is $1 \mathrm{GPa}$ and fluid excess pressure is $5 \mathrm{MPa}$, tensile stress is concentrated at hydrofractures tips in limestone layer close to lithology contacts and elongated following the geometry of lithology contacts. It suggests that hydrofractures tend to be deflected following the geometry of lithology contacts. Although, in places like in Figure 10, tensile stress is observed concentrated in shale next to contacts close to the tip of right-side hydrofracture. A new hydrofracture is possibly initiated in shale as the tensile stress concentration overcome the tensile strength.

In this model, fractures are deflected in the contact between limestone and shale if the difference in Young's modulus is significant (for example: $E_{l s t}$ $=10 \mathrm{GPa}$ and $E_{s h}=1 \mathrm{GPa}$ ). New hydrofractures is formed in shale layers if the tensile stress is concentrated in shale layers. It could be happened if the contrast in Young's modulus decreases and fluid excess pressure increases. 


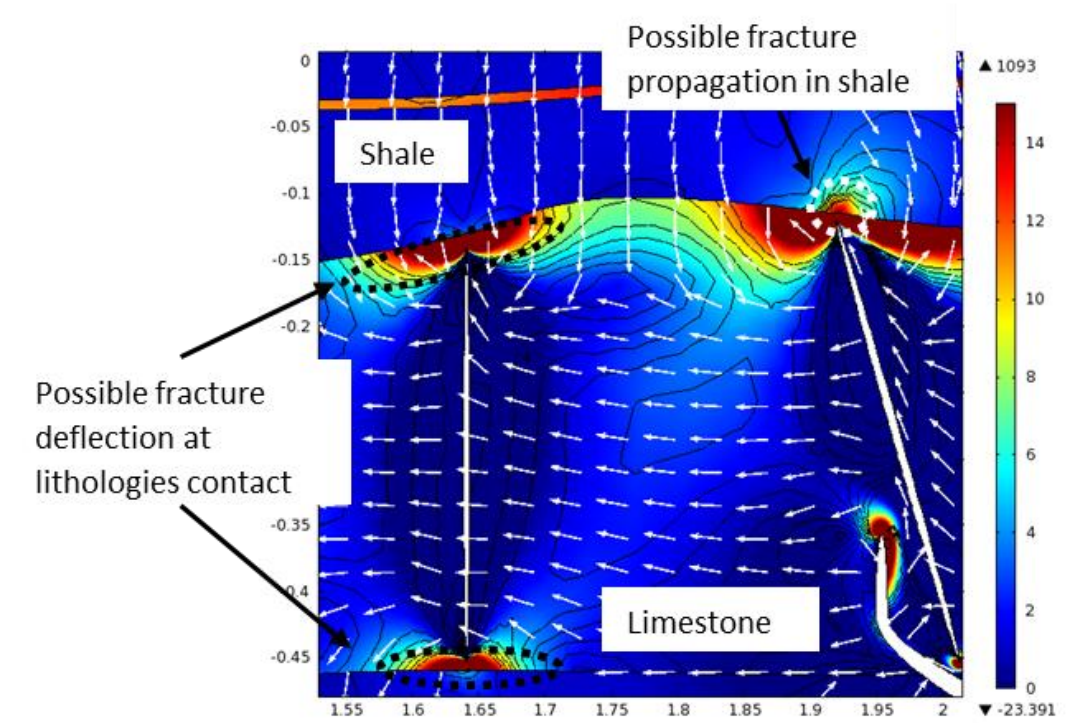

Figure 10. Detail of numerical modelling of model 3 under condition where Young's modulus of shale is $1 \mathrm{GPa}$ and fluid excess pressure is $5 \mathrm{MPa}$, showing fractures propagation white dotted lines) in shale at lithology contact and deflection of previous hydrofracture (black dotted line). White stick arrows represent direction of $\sigma_{l}$.

\section{CONCLUSIONS}

Based on model 1,2 and 3 , the layering of sedimentary rock influences the development of fracture if there is fluid excess pressure that work on hydrofractures. The difference in Young's modulus controls the tensile stress concentration under burial condition of $3000 \mathrm{~m}$ depth. Tensile stress concentration is concentrated in stiffer layers (limestone). The higher contrast in Young's modulus, the higher tensile stress concentration in stiffer layers. The linkage between hydrofractures can form shear fracture through shale layers and en-echelon shear fracture within limestone layers. Hydrofractures could be deflected if the tensile stress is only concentrated in stiffer layers or propagate through shale layers if the tensile stress is concentrated in shale. The layering of sedimentary rock could cause the contrast in Young's modulus which influence the stress concentration across rock layers. The decrease of the contrast in Young's modulus and the increase of fluid excess pressure would rise the probability of fracture initiation, fracture linkage, and fracture propagation.

\section{ACKNOWLEDGEMENTS}

This paper is a part of author's work during the master study at Royal Holloway, University of London. The author thanks to Indonesia
Endowment Fund for Education (LPDP) for funding the master study. The author also would like to thank Agust Gudmundsson, Lecturer of Advanced Structural Modelling Course. Constructive comments and suggestions from the reviewer and the editor are highly appreciated.

\section{REFERENCES}

Ahr, W. M., 2008. Geology of Carbonate Reservoirs: The Identification, Description, and Characterization of Hydrocarbon Reservoirs in Carbonate Rocks, DOI :10.1002/9780470370650.

Bons, P. D., Elburg, M. A., and Gomez-Rivas, E., 2012. A review of the formation of tectonic veins and their microstructures. Journal of Structural Geology 43, 33-62. DOI : 10.1016/j.jsg.2012.07.005.

Brenner, S. L., and Gudmundsson, A., 2002. Permeability development during hydrofracture propagation in layered reservoirs. Norges geologiske undersokelse Bulletin 439, 71-77.

Gillespie, P. A., Walsh, J. J., Watterson, J., Bonson, C. G., and Manzocchi, T., 2001. Scaling relationships of joint and vein arrays from The Burren, Co. Clare, Ireland. Journal of Structural Geology 
23(2-3), 183-201. DOI :10.1016/S0191-8141(00)00090-0.

Glen, R. A., Hancock, P. L., and Whittaker, A., 2005. Basin inversion by distributed deformation: The southern margin of the Bristol Channel Basin, England. Journal of Structural Geology 27(12), 2113 2134. DOI :10.1016/j.jsg.2005.08.006.

Gudmundsson, A., 2011. Rock Fractures in Geological Processes, DOI :10.1017/ CBO9780511975684.

Gudmundsson, A., Fjeldskaar, I., and Brenner, S. L., 2002. Propagation pathways and fluid transport of hydrofractures in jointed and layered rocks in geothermal fields. Journal of Volcanology and Geothermal Research 116(3-4), 257278. DOI : $10.1016 / \mathrm{S} 0377-0273(02)$ 00225-1.

Khoei, A. R., Hirmand, M., Vahab, M., and Bazargan, M., 2015. An enriched FEM technique for modeling hydraulically driven cohesive fracture propagation in impermeable media with frictional natural faults: Numerical and experimental investigations. International Journal for Numerical Methods in Engineering 104(6), 439468. DOI : $10.1002 / \mathrm{nme} .4944$.

Larsen, B., and Gudmundsson, A., 2010. Linking of fractures in layered rocks: Implications for permeability. Tectonophysics 492(1-4), 108-120. DOI : $10.1016 /$ j.tecto.2010.05.022.

Larsen, B., Gudmundsson, A., Grunnaleite, I., Sælen, G., Talbot, M. R., and Buckley, S. J., 2010. Effects of sedimentary interfaces on fracture pattern, linkage, and cluster formation in peritidal carbonate rocks. Marine and Petroleum Geology 27(7), 1531-1550. DOI :10. 1016/j.marpetgeo.2010.03.011.

Matte, P., 2001. The Variscan collage and orogeny (480-290 Ma) and the tectonic definition of the Armorica microplate: A review. Terra Nova 13(2), 122-128. DOI :10. 1046/j.1365-3121.2001.00327.x.

Maugis, D., 2000. Contact, Adhesion and Rupture of Elastic Solids Springer S, Springer,
Berlin, Heidelberg. DOI :10.1007/9783-662-04125-3.

Mohammadnejad, T., and Andrade, J. E., 2016. Numerical modeling of hydraulic fracture propagation, closure and reopening using XFEM with application to in-situ stress estimation. International Journal for Numerical and Analytical Methods in Geomechanics 40(15), 2033-2060. DOI :10.1002/nag.2512.

Peacock, D. C. P., 2002. Propagation, interaction and linkage in normal fault systems. Earth-Science Reviews 58(1-2), 121142. DOI : $10.1016 / \mathrm{S} 0012-8252(01)$ 00085-X.

Peterson, R. E., 1955. Stress Concentration Design Factors: Charts and Relations Useful in Making Strength Calculations for Machine Parts and Structural Elements, Wiley.

Philipp, S. L., Afşar, F., and Gudmundsson, A., 2013. Effects of mechanical layering on hydrofracture emplacement and fluid transport in reservoirs. Frontiers in Earth Science 1. DOI :10.3389/feart.2013. 00004.

Pompe, W., 1971. I. N. Sneddon/M. Lowengrub, Crack Problems in the Classical Theory of Elasticity. (The SIAM Series in Applied Mathematics). VIII + 221 S. m. 57 Fig. New York/London/Sydney/ Toronto 1969. John Wiley \&amp; Sons, Inc. Preis geb. 140 s. net. ZAMM Zeitschrift für Angewandte Mathematik und Mechanik 51(3), 238-239. DOI :10.1002/zamm. 19710510317.

Valko, P., and Economides, M. J., 1995. Hydraulic Fracture Mechanics, John Wiley \& Sons.

Zhang, X., Jeffrey, R. G., and Thiercelin, M., 2007. Deflection and propagation of fluid-driven fractures at frictional bedding interfaces: A numerical investigation. Journal of Structural Geology 29(3), 396-410. DOI :10.1016/ J.JSG.2006.09.013. 